\title{
RENEWABLE ENERGY IN UKRAINE: TOWARDS NATIONAL ECO-MANAGEMENT
}

\author{
Katerina Fedorova*
}

\begin{abstract}
The national energy security and independence issue is currently the most important problem in Ukraine. Continuous political games around traditional energy import sources exhaust the Ukrainian economy and lead to a systemic crisis. Ukraine has a huge natural potential for the development of green economy, but sustainable development in Ukraine is still at the initial stage of its evolution. Certainly, the transition to renewable energy technologies will be an effective solution to the key energy, environmental, social and political crises in Ukraine. Thus, the main attention of the author is focused on the renewable energy sources, including solar, wind, hydro, biomass and geothermal. It is emphasized that Ukraine has its national production of technical equipment for each of these areas of renewable energy. Along with alternative energy development issues, the author opens a wide panorama of current political, economic, social and security problems in Ukraine, which are deeply interdependent. The author argues that at its current level of development, Ukraine needs a comprehensive update of national ecomanagement strategy and a rational use of the potential natural programme. This will help the country to overcome the crisis permanently, transit from being a consumerist economic model towards an environmentally sustainable economic development and to integrate completely into Euro-Atlantic structures.
\end{abstract}

Keywords: renewable energy, sustainable development, eco-management, eco-economy, Ukraine.

DOI: http://dx.doi.org/10.4314/jsdlp.v7i2.2

* PhD (Political Science, Ukraine), Member of the International Scientific Committee, 'Zwiastowaæ. Nauki i praktyki', Warsaw, Poland. www.fedorova@gmail.com 


\section{INTRODUCTION}

Starting in 1991 when Ukraine gained independence from the Union of Soviet Socialist Republics (USSR), Ukraine found the opportunity to design its national development strategy. It is somewhat disappointing, however, that 25 years after independence, the country still has no clear plan for sustainable development. Given the energy dependence on imported oil and gas, traditional power generation significantly affects Ukraine's national security. Furthermore, continuous corruption, oligarchy, and bureaucracy have led to extraordinary levels of poverty, as well as deep and systemic economic, political, environmental and social crises.

Ukrainian eco-management is at an early stage of development, given the transition from an over-exploitative, consumerist model towards an environmentally sustainable economic development. According to the revised Energy Strategy of Ukraine which terminates in $2030,{ }^{1}$ at least 30 per cent of electricity in the country must be produced from renewable sources. So, at this stage, the country needs a comprehensive conceptual update and national economic, social and environmental revival. This will help it to recover from the permanent crisis and move to a new level of sustainable development and EuroAtlantic integration.

Therefore, the purpose of this article is to conduct a comprehensive, interdisciplinary analysis of the complications and impetuses for renewable energy development in Ukraine, in the light of present policy confusion.

The multidimensional nature of sustainable development underlines the need for a complexity of perspectives: environmental, political, geopolitical, economic, behavioural, social and security. The research methodology used was based on a systemic approach to the present stage of sustainable renewable energy development in the country. Furthermore, a neo-institutional analysis was conducted to study the specific features of national eco-management, in the context of rising corruption, oligarchy, and bureaucratic crises in the country. The critical-dialectical method makes it possible to understand the internal conflict-generating interrelations between political, social, environmental, energy and business problems in Ukraine.

1. Енергетична Стратегія України на Період до 2030 р.' 2013, s 7. 
The article, in a holistic and logical manner, discusses the renewable energy developments in Ukraine. Section 2 describes the main features of the solar power industry in Ukraine. Section 3 focuses on the key issues and innovations in the field of wind power energy. Section 4 identifies the impacts and opportunities of hydro energy generation. Section 5 emphasizes the complications and impetuses for biomass energy development. Section 6 reveals specific features of the geothermal energy generation in Ukraine. Section 7 concludes the article in accordance with the stated purpose.

\section{SOLAR POWER}

Climate conditions for solar power development in Ukraine are highly favourable. The amount of solar energy that gets released into Ukraine in three days is higher than the annual energy consumption of electricity in the country. The biggest potential of solar energy power can be found in the Southern regions of the state, located along the Black and Azov Seas, and particularly, the Crimean Peninsula. Yet, solar power generation in these regions has had a relatively poor development. Such background attracts foreign investors with diversified skill sets and interests to develop new solar power markets. The successful implementation of international and national $\mathrm{PV}^{2}$-projects in the Crimea, Odesa, Mykolaiv, Vinnytsia, Zakarpattia, Rivne and Kirovohrad regions creates extensive opportunities for sustainable, environmentally friendly and highly efficient satisfaction of local demand in electricity.

According to one international ranking, in 2011, the Ukrainian power Perove, the Crimea, was a world leader in the production of large-scale PV power plants. ${ }^{3}$ As of 2016, Perove is among the Top 50 in the same ranking. A strategic investor in the construction of solar power generation plant was Activ Solar $\mathrm{GmbH}$, an international group of companies, headquartered in Vienna, Austria. This company specializes in engineering, development, and construction of large-scale solar power plants based on high technologies. Overall, for the period 2011-2015, Activ Solar established more than 540 MWp of solar power equipment (from the $800 \mathrm{MWp}$ of installed capacity in Ukraine). This

2 Photovoltaic.

3 Large-Scale PV Power Plants - Top50 < www.pvresources.com/en/top50pv.php $>$ accessed 10 February 2016. 
helped to reduce $\mathrm{CO}_{2}$ emissions to 550 thousand tons per year and form a national demand for sustainable energy. The process of construction, installation, continued maintenance, and usage of new equipment of power systems has created more than 3,800 jobs across the country, raising employment of the local population.

Owing to the installation growth and the solar PV industry development, national legislation advanced to liberalize business in this field both for the national and foreign investors. Currently, according to the 2013 amended Ukrainian law on electric power generation, a Green tariff was set for Ukraine. Under this law, the state guarantees the purchase of all electricity produced with renewable energy by Green tariff till 2030. The rates of Green tariff for electricity generated from solar energy with land power objects are as follows:

- 3,15 for the objects launched in 2015-2019-;

- 2,80 for the objects launched in 2020-2024-;

- 2,45 for the objects launched in 2025-2029. ${ }^{4}$

Also, in the case of Ukrainian investor uses for services and/or materials, both fully or partially, a special allowance of the Green tariff of five per cent was set. If the Ukrainian component in the project is around 30-50 per cent, the allowance increases up to 10 per cent. A certificate issued by the Ukrainian Chamber of Commerce and Industry must confirm Ukrainian origin of equipment. Before 2015, the usage of Ukrainian component in the project was mandatory, for now, it is optional.

The leading Ukrainian companies that work in the solar energy industry include Ukrainian Association of Renewable Energy, Rener Group of Energy Companies, Rengy Development Group of Energy Companies, Rentechno LLC, and others. These companies provide a technical assessment of national energy infrastructure, plan projects, construct solar power modules, and also ensure further technical maintenance, monitoring of the electricity generation and its transmission to the local networks. Currently, the state of Ukraine's economy limits the ambitions to intensify the alternative energy development. That is why Ukrainian companies unite in associations, ${ }^{5}$

4 Law of Ukraine 'On Amendments to the Law of Ukraine on Electric Power' 2013, art 4, 17-1.

5 Association of Ukrainian Banks <http://aub.org.ua/index.php?option=com content\&task $=$ view\&id $=10994 \&$ Itemid $=134 \&$ lang $=$ en $>$ accessed 17 June 2016. 
groups and work closely with the European Bank for Reconstruction and Development (EBRD), ${ }^{6}$ Clean Technology Fund (CTF) ${ }^{7}$ and the Global Ecological Fund through the United Nations for Industrial Development (GEF/ UNIDO). ${ }^{8}$

Ukraine also has a national production line for solar systems and installations - PJSC Kvazar. This organization is a leader in the solar energy industry and the largest developer and producer of integrated circuits, PV cells and silicon wafers in Eastern Europe. Annual production in the factory is about $20 \mathrm{MW}$. In fact, only 1 per cent of its production is used in the national market, because the Ukrainian consumers often prefer lower-quality Chinese analogues, as they are cheaper by 20-30 per cent. Therefore, most of Kvazar's products are often exported to Europe, Asia, America, Africa and the Middle East. Obviously, this is not an acceptable approach to the development of renewable energy industry nor is it in the national interest of Ukraine as a whole.

Other countries already have learnt to place a special duty on solar modules imported from China, because Chinese companies offer solar equipment at very low prices that affect supply from other countries. However, policies to protect the Ukrainian national market and support national producers are still in the process. Moreover, a majority of Ukrainian companies are intermediaries who sell Chinese and other imported solar panels. By this, they only complicate the demand for national products and transform the renewable energy industry into import-oriented one even when the country has large national potential for the development of the same product. Certainly, it is always easier to buy and sell something made by others than to develop your own and market it to others.

However, Ukraine has the capability to develop innovative solar power installations. By the end of 2016, the first factory in Ukraine

6 Ukraine (European Bank for Reconstruction and Development, 2016) < http:// www.ebrd.com/ukraine.html> accessed 13 July 2016

7 Ukraine (Climate Investment Funds, 2015) <www-cif.climateinvestment funds.org/country/ukraine> accessed 12 July 2016.

8 Project of Global Ecological Fund through the United Nations for Industrial Development (GEF/UNIDO), 'Improvement of Energy Efficiency and Encouragement of Renewable Energy Utilisation in Agricultural and Foodstuff and other Small and Medium Enterprises (SME)' (State Agency on Energy Efficiency and Energy Saving of Ukraine 2013) < http://saee.gov.ua/en/ content/project-global-ecological-fund-through-united-nations-industrialdevelopment-gefunido-> accessed 12 July 2016. 
that produces organic solar cells will open, and this will be one of the few in the world. Solar panels of this type are made without silicon, which is difficult to recycle after use without harming the environment. In addition to its environmental friendliness, the significant feature of organic solar cells is their lower production cost, as they are thinner, smaller, lighter and better absorb solar energy than non-organic solar cells. ${ }^{9}$ In the construction process, developers plan to use only Ukrainian materials that are widely available in Ukraine. Japanese experience as one of the most high-tech and innovative markets in the world indicates that the development of such products is still at an early stage because their effectiveness can still be improved significantly before being deployed into the market. ${ }^{10}$

\section{WIND POWER}

The geographical location of Ukraine is favourable to wind power development. The country has potential for wind farm constructions. The highest level of wind energy potential can be found in the Crimean and Donetsk regions, as well as among the Carpathians. There are 13 wind farms in Ukraine: 10 in the Crimea and one each in Donetsk, Mykolaiv and Lviv. The key problem at the moment is that the majority of wind energy facilities are on the occupied territories of the Crimea and Donbas. These territories are beyond Ukrainian control, so legal wind power production and further construction of the earlier planned wind farms projects are currently impossible. Military and political instability in Ukraine slows down many innovative projects, significantly worsens the investment climate in all sectors of the economy and exacerbates the present economic crisis in the country.

Nevertheless, other regions have satisfactory locations for wind farm installations and operations, including Kherson, Kharkiv, Poltava, Dnipro, Odesa, Mykolaiv, Kirovohrad, Zaporizhzhia, Zakarpattia and Ivano-Frankivsk regions. According to the official data of the Ukrainian

9 Beate Burkhart and Barry C. Thompson, 'Solution-Processed Donors' in Barry P. Rand, and Henning Richter (eds), Organic Solar Cells: Fundamentals, Devices, and Upscaling (Pan Stanford Publishing 2014) 3, 5.

10 Kazuaki Nagata, 'As Technology Improves, Future of Organic Solar Cells Looks Bright' (2016) The Japan Times <www.japantimes.co.jp/news/2016/02/07/ business/tech/technology-improves-future-organic-solar-cells-looks-bright/ \#.V4dT8sar-IV > accessed 10 February 2016. 
Wind Energy Association (UWEA) for 2015, all electricity obtained from wind energy on the mainland Ukraine (excluding the Crimea peninsula) amounted to 1125 million $\mathrm{kW}$ of electricity, which has reduced $\mathrm{CO}_{2}$ emissions by more than 1329 million tons. ${ }^{11}$

It should be noted that the EBRD and the CTF launched Staryi Sambir-1, the first wind farm in the Carpathians, in March 2015. Project Staryi Sambir-1 was built in the Lviv region by Eco Optima, a Ukrainian developer that specializes in the development and implementation of sustainable and renewable technologies using the wind, solar, water and biomass energy. The capacity of Staryi Sambir-1 is 13,2 MW, and that provides more than 30 per cent of the energy needs of the Staryi Sambir district, the Lviv region. ${ }^{12}$ Although these steps are small, they show that despite essential political, economic and military problems, the Ukrainian wind power market continues to develop. It can become a rationale for the promotion of Ukraine's wind power interests at national and international levels.

For example, in May 2016 wind farm Ochakivska, Mykolaiv region, continued its expansion. In the previous year, this wind farm generated almost 130 million $\mathrm{kW}$ of electricity, which provided electricity to 50, 000 households. ${ }^{13}$ Construction of the wind park Prychornomorsky became the sixth stage of wind farm Ochakivska. Prychornomorsky has three wind power plants with the capacity for 2; 2,5; and $3 \mathrm{MW}$, respectively. Its special feature is that wind turbines for its construction were made in Ukrainian fabric in Kramatorsk in cooperation with the German company, Fuhrlander Windtehnology-Ukraine. ${ }^{14}$ This was the first post-Soviet era company to produce contemporary wind turbines. For now, it is a member of the Management Company Wind Parks of Ukraine, which won the tender in 2013 to build the first wind power station in Kazakhstan, using the megawatt-class system. ${ }^{15}$

11 Statistics (UWEA) < http://uwea.com.ua/en/library/stats/ > accessed 15 July 2016.

12 Projects (Eco Optima LLC) < www.ecooptima.com.ua/en/projects/ > accessed 16 July 2016.

13 News (Mykolaiv State Region Administration) < www.mk.gov.ua/en/news/ ?id $=28224>$ accessed 10 July 2016.

14 Windfarm Ochakov (LLC Fuhrlaender Wind Technology) < http://fwt.com.ua/ en/?p=91 > accessed 16 July 2016.

15 Production (LLC Wind parks of Ukraine) < http://wpu.com.ua/en/production/ $>$ accessed 13 July 2016. 
Ukraine has the capability to produce wind plants, including the Fly-Tech, Flamingo Aero, Windelectric and others. In addition to traditional wind turbines, Ukrainian scientists should pay special attention to innovative and technological researches in the field of sustainable development. Their contributions are recognized worldwide and have received high distinctions. In particular, Ukraine won the Green Inventions Competition 2013, which took place in Nuremberg, Germany and the Green Oscar Prize from the International Federation of Inventors' Associations (IFIA). ${ }^{16}$ The Green Oscar, received by Ukrainian scientist, Professor Oleksiy Onipko, was for creating Onipko Rotor wind turbine, a unique contribution in the world. A key feature of this wind turbine is its ability to work at low wind speed $-0,1 \mathrm{~m} / \mathrm{s}$, whereas traditional blade turbines usually begin spinning at a speed of 3-6 m/s. ${ }^{17}$ Innovation also has a wide range of power capacities and optional choice of materials and colours. The construction is very light, making it possible to use it for domestic needs and small farms.

Onipko Rotor solves the main problem of wind power: it does not create noise, does not violate the ecological environment, flora and fauna, and does not inconvenience human life in any way. Nevertheless, having such an innovative incentive in Ukraine has not changed things much. The traditional power resources remain the priorities of the state, which is the main debilitating factor for the Ukrainian economy. Moreover, scientists around the world are seriously interested in the production of Onipko Rotor wind turbine, while Ukrainian scientists still keep silent. This is not the only case of calmly ignoring or undervaluing the national potential and contribution of local inventors. They are common experiences. Thus, while other countries have identified scientific, technological, innovative and intellectual development as strategic priorities and have thus become high-tech world leaders, Ukraine, with its huge potential, ignores it. Such attitude has continued for decades and now leads to the exodus of Ukrainian scientists abroad. ${ }^{18}$

16 Green Inventions Competition 2013 (IFIA) < www.ifia.com/en/about/activityreport/report-2010-2014/report-in-2013/item/392-green-inventionscompetition-2013 > accessed 25 May 2016.

17 Specifications (Onipko Rotor) < http://onipko.com/characteristics/ > accessed 29 May 2016

18. Олег Білорус, Юрій Мацейко, Глобальна Перспектива і Сталий Розвиток (МАУП 2005) 16-17. 
The leading developers of the wind energy industry in Ukraine are Management Company Wind Parks of Ukraine, Wind Power (DTEK Renewables) and Windkraft Ukraine. The largest and most advanced wind farm in Ukraine is Botievska, which is among the top 5 in the Central and Eastern Europe region. Wind Power developed Botievska with a capacity of $200 \mathrm{MW}$ which can reduce carbon dioxide emissions by over 730000 tons. ${ }^{19}$ Electricity obtained from this station is supplied into the Interconnected Power System (IPS) of Ukraine.

In general, wind power industry developers in the Ukrainian market target different markets, ranging from producing to meet the needs of turnkey businesses to the installation of used wind power equipment from Europe, which is much cheaper than new wind turbines. The services are targeted at different budgets for customers, who seek energy independence for their businesses and stable income and the accompanying Green tariff from the sale of electricity to the state. It should be noted that the rate of Green tariff for electricity generated from wind energy by wind farms consisting of wind turbines with installed capacity of $2,000 \mathrm{~kW}$ each or more is:

- $\quad 1,89$ for the objects launched in 2015-2019;

- 1,68 for the objects launched in 2020-2024; and

- 1,47 for the objects launched in 2025-2029. ${ }^{20}$

As things are, alternative energy developed at $\mathrm{SME}^{21}$ level, which is used to support these enterprises cannot last, given current tariffs on traditional energy sources in Ukraine. One of the actual trends in Ukraine is the growing use of low-power wind turbines, which are installed by households for private purposes. Small wind power installations (up to $20 \mathrm{~kW}$ ) are attractive as they are fast enough to install. They are the best options where there are no other energy sources or when connecting to existing networks is too expensive.

There are a number of problems, however, which cause wind power industry to develop slowly. Among these are inefficiency of the national equipment, poor competitiveness, and limited innovative and technological development projects. That is why Ukraine needs, in

19 Botievo Wind Farm (DTEK) < http://botievskaya.dtek.com/en/ > accessed 19 June 2016.

20 Law of Ukraine (On Amendments to the Law of Ukraine on Electric Power) 2013, art 4, 17-1.

21 Small and Medium Enterprises. 
addition to its high natural capital, a comprehensive innovative technological cooperation with international companies. Ukrainian scientists have repeatedly stressed that the total potential of Ukrainian electricity produced from alternative energy sources can fully satisfy the country's needs. Potentially, Ukraine can be energy independent. But for this to happen, there must be political will and a comprehensive state programme for the development of existing potential. This does not exist at the moment.

\section{HYDROPOWER}

The problem of water resources is one of the key issues of sustainable development and environmental security in Ukraine. The country is endowed with two seas, the Black sea and the Azov, and also by more than 63,000 rivers. Owing to global environmental changes and unsustainable national eco-management, however, about 20, 000 rivers have been disappearing over last 20 years. ${ }^{22}$ At the moment, the water resources of Ukraine are in a disastrous state given a number of critical issues:

- Municipal and industrial water purification is insufficient, inefficient and sometimes even absent;

- Agricultural, metallurgical, energy, coal and wood industry wastes destroy the ecosystem;

- Nearly half of the contaminated water effluents in the state are municipal wastes;

- Outdated, technically worn-out installations on pumped hydroelectric energy storages (PHES) accumulate contaminants and cause environmental pollutions;

- The condition of abandoned small and large hydropower plants that did not work for decades is critical, unsafe and insecure. This leads to a significant shallowing and overgrowing of channels and rivers, and the formation of areas of stagnant water;

22. Инна Гончарук, 'Татьяна Тимочко: «В Украине Исчезло Более 20 Тысяч Водных Объектов, на Очереди Шацкие Озера»' (Golos.ua, 16 July 2013) <http://ru.golos.ua/su spilstvo/13_07_16_tatyana_timochko_v_ukraine_ ischezlo_bolee_20_tyis yach_vodnyih_obyektov_na_o $>$ accessed 11 May 2016 . 
- Thousands of kilometres of sewerage networks built during the Soviet era are in disrepair, extremely outdated and overloaded. Hundreds of settlements still have no centralized sewerage;

- Illegal deforestation and conversion of forestland into urban areas or private housing development drains the bogs, weakens the ecosystem, and makes the entire process dysfunctional;

- Illegal construction along the shoreline of seas and rivers signals not only official corruption but also highlights a severe ecological crisis.

In such circumstances, rivers lose their self-cleaning ability. Every year they are polluted by hundreds of thousands of tons of oil products, organic waste, chlorides, sulphates and debris. Arising from this, 80 per cent of water in Ukraine does not meet the quality standards. Moreover, water scarcity is a growing problem, and tens of thousands of settlements have no drinking water. ${ }^{23}$ So, the problem of water resources of Ukraine is a nationwide issue that needs immediate, wholeof-government consolidated approach to solve.

In this context, hydropower can be considered a constructive solution to the water problems of Ukraine as well as a destructive environmental challenge. There is a pressing problem of ecooptimization of the operations of the Ukrainian water reservoirs. The country needs eco-management effectiveness, the construction quality of new PHES, and an accurate and timely upgrade of old systems, monitoring of their functioning, and stimulation of eco-innovations. Notably, the construction of hydropower plants on Ukrainian rivers currently results in significant environmental, social and financial losses given the accompanying inundation of the territories with water reservoirs. It is to be mentioned that during the construction of the Dnieper PHES cascade ${ }^{24}$ measures were targeted to avoid the inundation of hundreds of villages. The Soviet Government forcibly moved thousands of people. Such large-scale construction of PHES

23 ibid.

24 The Dnieper PHES cascade consists of six levels: 1 cascade - the Kyiv Hydroelectric Power Plant (HPS) - constructed and launched 1964-1968; 2 the Kaniv HPS - 1963-1975; 3 - the Kremenchuk HPS - 1954-1960; 4 - the Dniprodzerzhynsk HPS - 1956-1964; 5 - the Dnieper HPS - 1927-1932; 6 the Kakhovka HPS - 1950-1956. 
was the first in the USSR, and the Dnieper PHES cascade had no analogues in the world. ${ }^{25}$ However, its construction resulted in an ecological crisis and deep social conflicts, with impacts still felt all over the place. Therefore, the Ukrainian hydropower has to develop, while accounting for all the possible consequences of its operation.

Hydropower resources eco-management has been ineffective, irresponsible and predatory over the 25 years of Ukraine's independence. Now, in the context of current European integration processes in Ukraine, there have been some changes. One of the strategic goals of the Ukrainian government was the integration of Ukraine's IPS into the European electricity network. On 13 July 2016, the Cabinet of Ministers of Ukraine approved the ten-year Programme for Hydropower Development, which runs till 2026. The programme provides for the reconstruction and modernization of existing PHES, including the building of new hydropower installations. It is expected that in 10 years, the 2026 Programme will increase hydroelectric power production in the country from the existing 8.6 per cent to 15.5 per cent. ${ }^{26}$ The 2026 Programme also includes completion of those PHES, which have been pending since the Soviet era. The special attention is being given to the Dniester PHES modernization, which currently operates with capacity 324 MW. It is expected to enhance this PHES up to 2268 MW capacity. On completion, the Dniester PHES will be the most powerful in Europe and the sixth of such in the world. ${ }^{27}$

Also, one of the effective ways of actively propagating renewable energy use in Ukraine is through small hydro development. There are many advantages to be derived from this approach. One, it does not require large investments; it quickly covers the cost of its purchase; and it can provide power in very inaccessible areas. ${ }^{28}$ After the Second World War, there were about 3,000 small hydro installations scattered around Ukraine, but now there are only 70 and they operate with a

25 Сергій Дубняк, 'Еколого-Гідроморфологічний Аналіз Проблем Підтоплення Земель у Зоні В пливу Дніпровських Водосховищ' (2007) 256 Наук. прац і УкрНДГМІ 293, 293.

26 Уряд Схвалив Програму Розвитку Гідроенергетики України на Період до 2026 року (Cabinet of Ministers of Ukraine, 14 July 2016) <w ww.km u. gov.ua/con trol/en/publish/article?art_id $=249190490 \&$ cat_ $\mathrm{id}=244274160>$ accessed 15 July 2016

27 ПАТ Укргідроенерго < http://uge.gov.ua/ > accessed 17 May 2016

28 Геннадій Півняк, Федір Шкрябець, Альтернативна Енергетика в Украӥні (НГУ 2013 ) 33. 
total installed capacity of $110,74 \mathrm{MW}$. Abandoned small hydro stations are in precarious conditions and have become a threat to people and the environment. The urgent task for Ukraine's eco-development is to optimize workable small hydro installations and to dismantle those that cannot be repaired. Then, the engineering of new, small hydro plants can be done sustainably and efficiently.

The most promising locations for the construction of small hydro stations are the mountainous areas because of the possibility of using the potential of very small water sources. ${ }^{29}$ Therefore, the most promising areas for these projects in the country are Zakarpattia and Lviv regions, which have a concentration of about 70 per cent water capacity of small rivers. Choosing the right equipment is of paramount importance in the construction of small hydro projects. The landscape, as well as the climatic and ecological conditions is different in the various regions of Ukraine. It is incorrect, therefore, to buy the same equipment for all hydro stations in the country. Each piece of equipment must be chosen for a particular location. In practice, the equipment that works perfectly in one area can be dangerous, unprofitable and unsustainable in another.

Ukraine has its own production of small hydro turbines made by Minihydro which target the national and international markets. In the Ukrainian market, investors have a wide choice of German, Czech and Slovak equipment, but Ukrainian turbines are cheaper, and the national equipment usage can increase the company's profit. The engineering, construction and further servicing of the new, and restoration of the abandoned small hydro stations (up to $10 \mathrm{MW}$ ) can be done easily by Ukrainian companies such as Vinnytsia Spetsenergo Montazh, Mayak, Ukrelektrobud, and Promenergia. ${ }^{30}$ The impetus to restore power generation in this area is a Green tariff. It covers the hydropower produced with micro, mini and small hydroelectric power stations, where power capacity does not exceed $10 \mathrm{MW}$. The Green tariff rate for electricity generated by small hydro is:

29 Сергей Бумарсков, 'Об Опыте Проектирования Гидротурбин для Низконапорных и Высоконапорных Малых ГЭС’ (2013) 2(62) Вісник НУВГП 309, 311.

30 ibid 313. 
- 1.08 for the objects launched in 2015-2019;

- 0.96 for the objects launched in 2020-2024; and

- 0.84 for the objects launched in 2025-2029. ${ }^{31}$

However, there are some problems related to the construction and operation of small hydro power stations. For example, in the Carpathian region, it causes the disappearance of hundreds of rivers and degradation of tourism. The solution for hydropower development problems in Ukraine has a national significance because by working effectively small hydro projects can protect surrounding cities from floods, contribute to their normal water supply and facilitate the development of the fishing industry. Policymakers and the larger society should note, therefore, that no economic benefit can justify the degradation of human health and the environment. Sustainable development requires an integrated approach to the implementation of a green energy programme, taking into account all the environmental, social and technological peculiarities of each region. Responsible governance and systematic monitoring will provide the opportunity to create a qualified and effective eco-management in Ukraine. ${ }^{32}$

\section{BIOMASS ENERGY}

Among all renewable energy sources in Ukraine, the most promising is bioenergy technologies - that is, the production of biomass and biofuel. Biomass is an alternative energy source obtained from human and animal waste, and also from wood and agricultural industry waste. The biomass potential in Ukraine is almost unlimited, ranging from fallen leaves to the pig farms waste. Also, biomass can be produced from plants specially grown to meet the energy needs of people and the industry. ${ }^{33}$ The availability of biomass resources makes the Ukrainian market more competitive, profitable and free; moreover, global demand

31 Law of Ukraine (n 20) art 4, 17-1.

32 Тетяна Тимочко, 'Екологічні Проблеми у Контексті Сталого Розвитку' in Анатолій Садовенко (eds), Сталий розвиток суспільства: навчальний посібни к (ПРООН 2011 ) 119, 121.

33 Biomass Use (Climate Change and Biodiversity Projects in Belarus and Ukraine) www .restoringpeatland s.org/index.php?o ption $=$ com_content \& view $=$ article $\& \mathrm{id}=78 \&$ Itemid $=17 \& \operatorname{lang}=\mathrm{en}>$ accessed 01 July $\overline{20} 16$ 
for it is constantly growing. In addition, biomass energy is sustainable, as it allows for waste recycling and electricity production.

However, Ukraine's eco-management in the biomass processing industry cannot be characterized as constructive and efficient. The country produces 110-120 million tons of biomass annually, whereas only 1 per cent is used for heat and electricity generation, while 45 per cent wasted. ${ }^{34}$ Ukraine also produces about 100,000 tonnes of biodiesel annually, although actual capacity is much larger (at least 500,000 tons). ${ }^{35}$ Ukrainian potential of corn, soy and rapeseed, as a feedstock for biofuel, opens broad perspectives for the country to develop the biodiesel industry. At the moment, Ukraine is a European leader in the export of rapeseed, but about 30 per cent of its revenue is lost because there are insufficient facilities for processing biofuel and further production of biodiesel, biogas, and bioethanol.

The availability of a high potential and its very minimal application is very common in almost all fields in Ukraine. Several factors are responsible for this. They include a complicated bureaucratic system for businesses that produce heat and electricity; inadequate funding; corruption; poor development and application of innovations and high technologies in this field. A particular case in point is the production of pellets which is still at the initial stage of development. ${ }^{36}$

Nevertheless, there are some constructive impetuses for biomass industry development. For instance, the ongoing European integration reform processes encourage Ukraine to follow principles of sustainable development, energy saving, and efficiency, and to switch to a green economy and clean energy technologies. Also, a positive factor is an increasing demand from the EU member countries for bioenergy products from Ukraine. Also, recent Ukrainian legislative initiatives are positive for the biomass energy development, including Green tariff that also applies to this energy sector. The Green tariff rate for electricity produced from biomass and biogas is:

34 Bioenergy \& Biobased Opportunities in Ukraine (June 2013 ) Tebodin Ukraine CFI Analytical Paper <http://english.rvo.nl/sites/default/files/ 2013 /1 2/B ioen ergy $\% 2$ 0op port unies\% 2 0in \%2 oU krain \%2 0\% 20 Tebo din $\%$ $20 \% 202013 . p d f>$ accessed 15 June 2016

35 Микола Дідух, 'Виробництво Біопалива: Світові Тенденції, Національні та Регіональні Перспективи' in Олег Скидан (eds), Персnективи Розвитку Альтернативноӥ Енергетики на Поліссі України (ЖНАЕУ $2014) 8,24$.

36 Bioenergy \& Biobased Op portunities in Ukraine (n 34). 
- 2,07 for the objects launched in 2015-2019;

- 1,84 for the objects launched in 2020-2024; and

- 1,61 for the objects launched in 2025-2029. ${ }^{37}$

Also, on 15 July 2016, the Prime Minister of Ukraine, Volodymyr Groysman, officially opened the most powerful heating boiler station in Vinnytsia, Ukraine. This is the result of a joint project with Switzerland. With energy produced by this eco-efficient boiler $(5,2$ MW), two districts of the city will be entirely provided by renewable energy. Current Ukrainian industry includes 4,000 of wood boilers, 100 of straw boilers and 70 sunflower husk boilers. Some of the Ukrainian CHPP ${ }^{38}$ operate on solid biomass, for instance, in a central heating system - on wood; and in the fat and oil industry enterprises on sunflower husk.

In the private sector, many people use wood-burning stoves and boilers. This was a result of the record triple hryvnia depreciation and simultaneous systematic increment of the tariffs for natural gas consumption from 2014-2016. Nowadays, the monthly payment for gas heating in private homes in cold seasons is equal to the minimum monthly salary and the subsistence minimum. ${ }^{39}$ This has resulted in the massive denial of central gas supplement and switching to the use of stoves and boilers. Tariff for natural gas consumption for industrial purposes is even bigger, and this led many enterprises and factories to bankruptcy between 2015 and 2016. Nevertheless, this situation can also be considered an incentive for the large-scale development of alternative energy in Ukraine. Production and use of biofuel in Ukraine's agriculture will increase rural employment, support rational use of abandoned land, encourage the sustainable development of local resources as well as effective eco-management.

In the international arena, Ukraine has one of the greatest agricultural potentials in Europe: it has a favourable climate and available labour force for the development of a bio-based economy. This makes Ukraine a highly attractive market for investment and

37 Law of Ukraine ( n 20) art 4, 17-1.

38 Combined heat and power plant.

39 According to the State budget of Ukraine 2016 as of 01 May 2016 - 30 October 2016 . the minimum monthly salary and the subsistence minimum are equal and is $1450 \mathrm{UAH}$ (around $\bullet 52$ ). Law of Ukraine 'On State Budget of Ukraine in 2016' 2016, art 7-8. 
innovation in biomass and biofuel industries, and alternative energy in general. Ukraine exports national biomass products to Poland, France, Germany, Belgium, the Netherlands and China. The Netherlands is particularly interested in cooperating with Ukraine in the field of bioenergy, was and this has repeatedly been demonstrated at the interstate level. The Netherlands' experience is very constructive and indicates that one of the best tools to guarantee sustainability in the production of biomass and biogas is certification. ${ }^{40}$ This strategy ensures full environmental friendliness of the production process that raises products quality. Moreover, fostering the promotion of quality products made with renewable or alternative energy helps Ukraine to create energy independence, which will undoubtedly strengthen its geopolitical and geostrategic position in Europe and the world. In this context, Ukraine should direct its efforts to the cultivation of scientific and innovative potential for certification and standardization in the field of sustainable development.

\section{GEOTHERMAL ENERGY}

Geothermal energy is based on the generation of power located in the bowels of the earth. It is the cheapest renewable source of heat energy that is available non-stop and does not depend on climatic or weather conditions. Geothermal energy has great potential to be used as a priority sustainable, clean and renewable energy production in Ukraine and in the world. It is also characterized by the lowest negative environmental impact among other types of renewable energy. Thermal energy consumption market is multifunctional and suitable for almost any type of need: industrial, commercial, agricultural and private. Moreover, the heat of the earth can be used to produce electricity as well as do several other things. More than 80 countries use their geothermal resources for a number of purposes, such as heating factories, enterprises, schools, private households, and swimming pools. They also use it for water heating in fish farms. ${ }^{41}$ In addition,

40 Tools for Sustainable Biobased Projects (Netherlands Enterprise Agency 2014) <http://english.rvo.nl/sites/default/files/2014/12/Tools\%20for\%20 Sustainable\%20Biobased\%20Projects.pdf> accessed 29 June 2016.

41 Antonio Barrero, 'Energías Renovables para Todos. Energía Geotérmica y del Mar' (2003) FENERCOM 2, 5. 
the construction of geothermal wells is relatively inexpensive, in comparison with other energy sources, and quickly covers the cost of its purchase (i.e., within 1-5 years).

Although recent high technologies can minimize negative environmental factors from geothermal energy production, pollution still exists. The key problem is that the thermal water contains a large number of toxic substances, which makes it impossible to dispose wastewater into natural water systems located on the surface. One of the solutions to this problem is to reverse pumping of wastewater into underground aquifers. But this technology requires additional equipment that significantly increases the cost of engineering needs (to 50 per cent).

Geothermal energy exists everywhere under the surface of the earth, but currently, only 10 per cent of the land suitable for its operation is explored. ${ }^{42}$ According to Ukrainian geologists' researches, the amount of Ukraine's explored geo-energy resources exceeds the reserves of traditional energy fuels. ${ }^{43}$ However, this type of power generation is still at the pilot production stage. Ukrainian scientists outline three geothermal active zones: the Crimean, Dnieper-Donetsk, and Western Ukrainian. ${ }^{44}$ At the same time, these areas have several favourable factors for the geothermal energy development: a lot of oil-producing stations that can be reoriented for the geothermal development; national electronic and heavy engineering that produces all the necessary equipment to build deep geothermal wells; and high population density, which can consume generated energy without transportation. ${ }^{45}$ For now, there are 11 geothermal power plants in Ukraine with most of them located in the temporarily occupied territories of the Crimea and Eastern regions of Ukraine.

Western Ukrainian geothermal active zone has great potential for the renewable energy industry. For example, the Zakarpattia geothermal area, estimated at $492.6 \mathrm{MW}$, consists of seven major areas, namely,

42 How Geothermal Energy Works (Union of Concerned Scientists, 22 December 2014) <w ww.ucsusa.org/clean_energy/our-energy-choices/renewable-energy /how-geothermal-energy-works. html \#bf-to c-1> accessed 21 July 2016.

43 Василь Карпенко, Володимир Стасенко et al., 'Геотермальні Ресурси України' (2013) 2 (46) Геоінформат ика 39, 40.

44 Уляна Палі йчук, 'Ви кори стання Геотермальної Енергії в Україні : Можливості та Перспективи’ (2012) 2(32) Науковий ві сник ІФНТУНГ 37, 38.

45 Юрій Стародуб, Василь Карпенко et al., 'Аспекти Оцінки та Освоєння Геотермальних Ресурсі в України’ (2012) 2(13) Геодинаміка 95, 95. 
Berehivsky, Kosynsky, Terebliansky, Uzhhorodsky, Veliatynsky, Velykopaladsky and Velykobaktynsky. ${ }^{46}$ Such resources are enough for the geothermal energy stations development and the needs of agricultural industry. In addition, well-developed engineering opens the possibility to improve the potential of small (50-5000 kW), big (10-50 MW) and combined (geothermal water + burning of organic fuel) geothermal energy stations in Ukraine.

However, so far, Zakarpattia geothermal potential has a positive impact only on the tourism industry. The first geothermal station there was built for heat supply purposes in the resort area in Berehovo in 1999. Thermal and mineral waters of Zakarpattia and spa resorts in Berehovo, Kosyno and Uzhhorod always attract tourists from all over Central and Eastern Europe. In addition to tourism, geothermal resources in Zakarpattia also attract European investors to implement projects for the geothermal energy development for the city and industry needs. However, Green tariff does not cover this power generation sector, and public administration has not yet expressed any interest in mutually beneficial cooperation.

\section{CONCLUSION}

Innovative development, promotion and implementation of renewable energy technologies can lead Ukraine to energy independence and create new employment opportunities. Innovative projects can be a powerful impetus for economic recovery with appropriate government support. By fostering the promotion of renewable energy production, Ukraine can increase its environmental security, offer its national products in the world market and achieve ecological waste disposal.

It is apparent that alternative energy industry in Ukraine had an intensive development before the economic crisis of 2014 and the counter-terrorism operations that followed. Foreign investors were interested in cooperation with Ukraine in this field, as this business became increasingly profitable and promising here. At the moment, a majority of the most powerful and strategic renewable energy projects are on temporarily occupied territories of the Crimea and Eastern regions. Therefore, all projects for engineering and construction of

46 Віталій Ремета, 'Термальні Води Закарпаття' (2011) 12(146) Энергосбережение 12, 13. 
renewable energy facilities located in these areas are frozen or stopped. Those projects carried out in other regions of Ukraine are not sufficient to stimulate the economy, achieve energy independence and reorient the state for environmentally sustainable economic development.

This research identified the main driving force of the renewable energy development in Ukraine as the small and medium enterprises and private households. This demonstrates the high level of public readiness to transition towards sustainable development model and indicates a well-developed environmental awareness of the Ukrainian people. Every year, an increasing number of people and enterprises adopt green energy in Ukraine; a lot of emerging organic farms in the country were reconstructed from abandoned conventional farms. Simultaneously, it also emphasizes the lack of a national strategy and constructive policy in the field of sustainable development and renewable energy. National eco-management should not be limited by Green tariff only. Ukraine needs dozens of programmes for environmental protection and economic stimulation of alternative and renewable energy. The country has the huge national natural capital to overcome its deep economic crisis and achieve energy independence. The most logical way is to use this natural potential efficiently, to maintain national innovations, to encourage international investors and to move towards a sustainable development model in a holistic manner. Moreover, this chance can still be used.

We can conclude that it is a very complicated task to achieve an ecological civilization in a highly bureaucratized society ruled by oligarchs. Sustainable development is a way to think, live, do business and public administration, and corruption is a great obstacle here. This concern goes beyond Ukraine; it is an issue in most countries of the world. Almost every country suffers from the corrupted system and poverty at the national or local level, or even both. It is the key barrier to the sustainable development progress and its cultivation in the country, and - as a consequence - in the international system. 